\title{
PENGARUH METAKOGNITIF TERHADAP HASIL BELAJAR PADA MATA PELAJARAN EKONOMI MELALUI EFIKASI DIRI SISWA
}

\author{
Lasmita Sihaloho, Universitas Pendidikan Indonesia \\ Lasmita_sihaloho@student.upi.edu \\ Agus Rahayu, Universitas Pendidikan Indonesia \\ agus_rhy08@upi.edu \\ Lili Adi Wibowo, Universitas Pendidikan Indonesia \\ liliadiwibowo@upi.edu
}

\begin{abstract}
ABSTRAK
Penelitian ini bertujuan untuk meneliti pengaruh metakognitif terhadap hasil belajar ekonomi melalui efikasi diri. Pengukuran metakognitif menggunakan the metacognitive assessment inventory (MAI) yang mengukur pengaturan kognisi dan pengetahuan kognisi. Pengukuran hasil belajar menggunakan nilai Ujian Akhir Semester (UAS) mata pelajaran Ekonomi. Pengukuran efikasi diri mencakup magnitude atau level, strength, dan generality. Populasi dalam penelitian ini adalah semua siswa kelas XI IPS SMA di Bandung. Sampel sebanyak 362 siswa diambil dengan menggunakan teknik proporsional random sampling. Metode penelitian adalah survey menggunakan pendekatan deskriptif. Data dianalisis dengan analisis jalur (path anlysis). Hasil penelitian menunjukkan bahwa (1) Sebagian besar siswa kelas XI IPS SMA di Bandung memiliki: tingkat metakognitif tinggi, tingkat efikasi diri tinggi, dan hasil pembelajaran ekonomi dalam kategori sedang; (2) Metakognitif berpengaruh positif dan signifikan terhadap efikasi diri; (3) Metakognitif berpengaruh positif dan signifikan terhadap hasil belajar ekonomi baik secara langsung maupun tidak langsung (melalui efikasi diri).
\end{abstract}

Kata Kunci: Metakognitif, Hasil Belajar Ekonomi, dan Efikasi Diri.

\begin{abstract}
This study is aimed at investigated the influence of metacognitive on learning outcome economic through self-efficacy. The Metacognitive Assessment Inventory (MAI) includes cognition and knowledge of cognition. Measurement of learning outcomes includes the value of the final examination of semester in Economic. Measurement of self-efficacy includes magnitude atau level, strength, and generality. The population in this study is all the students of class XI IPS senior high school in Bandung. The sample of 362 students was taken by using proportional random sampling technique. This method research is survey using descriptive approach. Data were analyzed with path analysis. The results indicated that (1) Most of the students of class XI IPS senior high school in Bandung have: high metacognitive level, high level of self efficacy, and learning
\end{abstract}


outcome of economic in medium category; (2) Metacognitive has positive and significant effect on self efficacy; (3) Metacognitive has positive and significant effect on learning outcome of economic either directly or indirectly (through self efficacy).

Keywords: Metacognitive, Learning Outcome of Economics, Self Efficacy.

\section{PENDAHULUAN}

Pencapaian peserta didik dalam belajar menjadi hal yang penting sebagai indikator dalam mengukur seberapa besar tingkat keberhasilan sistem pendidikan di Indonesia. Pencapaian tersebut dapat dilihat dari hasil belajar yang diperoleh oleh peserta didik. Pencapaian hasil belajar siswa dalam proses pembelajaran meliputi kognitif (hasil belajar), afektif (sikap) dan psikomotorik (keterampilan). Hal ini sejalan dengan pendapat (Scott, 2011) hasil belajar secara teori dapat menunjukkan berbagai tipe pengetahuan, keterampilan dan perilaku. Sejalan dengan pendapat Supranata (2007) dalam jurnal (Widarwati, 2007) bahwa hasil belajar meliputi aspek pembentukan watak seorang peserta didik, dengan demikian mengukur tiga aspek utama hasil pendidikan, yaitu aspek kognitif, afektif dan psikomotor. Hasil belajar adalah pernyataan tertulis tentang kemampuan atau kualifikasi apa yang diharapkan dapat dilakukan siswa untuk mencapai kesuksesan pada akhir materi pembelajaran (Adam, 2004).

Tujuan akhir dari kegiatan pembelajaran adalah adanya hasil belajar untuk mengetahui sejauh mana tingkat penguasaan siswa terhadap materi pelajaran setelah melaksanakan proses belajar. Pengertian tentang hasil belajar dipertegas oleh Nawawi dalam (Susanto, 2013) yang menyatakan bahwa hasil belajar dapat diartikan sebagai tingkat keberhasilan siswa dalam mempelajari materi pelajaran di sekolah yang dinyatakan dalam skor yang diperoleh dari hasil tes mengenai sejumlah materi pelajaran tertentu. Dalam sistem pendidikan nasional rumusan tujuan pendidikan, baik tujuan kurikuler maupun tujuan instruksional, menggunakan hasil belajar dari Benyamin Bloom yang secara garis besar membaginya menjadi tiga ranah, yakni ranah kognitif (pengetahuan), ranah afektif (sikap), dan ranah psikomotor (keterampilan) (Sudjana, 2012). Faktor-faktor yang mempengaruhi hasil belajar digolongkan menjadi dua yaitu Pertama yaitu faktor internal: faktor jasmaniah (berhubungan dengan kesehatan dan cacat tubuh), faktor psikologis (intelegensi, perhatian, minat, bakat, motif, kelelahan dan kematangan) dan faktor kelelahan. Kedua yaitu Faktor eksternal: faktor keluarga, faktor sekolah, dan faktor masyarakat (Slameto, 2010).

Berdasarkan data Programme for International Student Assessment (PISA) pada tahun 2015 Indonesia berada pada peringkat 69 dari 76 negara, dan data PISA 2015 tersebut menyatakan bahwa kurang dari lima persen siswa dari negara Indonesia yang mampu menjawab pertanyaan/soal yang kompleks seperti model matematika, refleksi, konseptualisasi, generalisasi, keterampilan pemahaman dan penalaran tingkat tinggi dalam kegiatan PISA tersebut (PISA, 2015). Hasil ini menunjukkan bahwa kualitas pembelajaran di Indonesia dan kemampuan siswa dalam penalaran tingkat tinggi berada pada kategori sangat rendah yang berdampak pada rendahnya hasil belajar siswa di Indonesia. 
Permasalahan rendahnya nilai hasil belajar siswa juga dapat dilihat pada nilai Ujian Nasional (UN) mata pelajaran ekonomi di SMA Negeri yang ada di Kota Bandung menunjukkan bahwa nilai Ujian Nasional (UN) tahun 2012 adalah 8,50, tahun 2013 adalah 5,84, tahun 2014 adalah 6,00, tahun 2015 adalah 6,11, dan terakhir tahun 2016 adalah 5,74. Rata-rata nilai Ujian Nasional (UN) mata pelajaran ekonomi di SMA Negeri yang ada di Kota Bandung adalah 6,44 berada pada kategori rendah yang tidak memenuhi nilai kriteria ketuntasan minimal (KKM) dari mata pelajaran ekonomi yaitu 75.

Untuk memaksimalkan pencapaian hasil belajar peserta didik, diperlukan pengoptimalan faktor-faktor yang mempengaruhinya. Salah satu faktor yang mempengaruhi hasil belajar adalah faktor internal yaitu metakognitif siswa. Istilah metakognitif yang diciptakan oleh John Flavell merujuk kepada kesadaran seseorang akan berpikir dan belajar: apa yang kita pikirkan, bagaimana kita berpikir dalam kaitannya dengan tugas belajar atau situasi dan mengapa kita berpikir dengan cara tertentu. Metakognisi juga mencakup kemampuan untuk mengatur proses pemikiran pada satu pengetahuan tentang proses, produk atau apapun yang berhubungan dengan kognitif itu sendiri (Flavell, J, 1979; Goh, 2016; Tok, 2013). Metakognisi didefenisikan sebagai perencanaan belajar, memecahkan masalah, mengembangkan kesadaran tentang proses berpikir dan mengatur proses pemikiran ini. Sebagai gambaran fungsional, metakognisi bagian dari kesadaran seseorang tentang bagaimana dia mengetahui, mencapai tujuan dan bagaimana menggunakan pengetahuan ketika dia tidak mengerti dan menyadari hal ini, serta menjadi kemampuan penilaian kognitif dalam tugas khusus, pengetahuan strategi yang terkait dengan tujuan dan evaluasi seseorang dalam proses atau setelah proses kognitif (Gourgey, 1998; Brown, 1978 dalam jurnal Kesici \& Özteke 2011).

Penelitian pendidikan dan kognitif pada saat ini menunjukkan bahwa sebagian besar siswa mengalami kesulitan dalam mengatur pembelajarannya dan melakukan aktivitas metakognitifnya secara langsung (Raes, Schellens, De Wever, \& Benoit, 2016). Siswa yang tidak memiliki keterampilan metakognitif tidak dapat menilai, memantau dan memecahkan masalahnya sendiri (Lucangeli, Cornoldi, \& Tellarini, 1997 dalam jurnal (Garrett, Mazzocco, \& Baker, 2006). Siswa yang memiliki sedikit keterampilan metakognitif akan terlihat pasif dalam kegiatan belajarnya, tidak dapat mengatur pembelajarannya secara mandiri, bahkan mungkin akan gagal dalam hasil belajarnya (Shen \& Liu, 2011). Oleh karena itu, meningkatkan keterampilan metakognitif menjadi dampak yang penting dalam proses pembelajaran karena proses pembelajaran dapat dikatakan berkualitas apabila siswa secara sadar mampu mengontrol proses kognitifnya yang berdampak pada hasil belajarnya (Wang, Haertel, dan Walberg, 1990 dalam jurnal (Bahri \& Corebima, 2015; Ninik Kristiani, Herawati Susilo, 2015; Shen \& Liu, 2011). Metakognitif memiliki peranan penting dalam kegiatan kognisi termasuk berpikir, memahami, berkomunikasi, mengingat, dan memecahkan masalah (Cañada \& Arumí, 2015; Listiana, Susilo, Suwono, \& Suarsini, 2016).

Metakognitif mengarahkan siswa bagaimana meningkatkan kesadaran berpikir dalam proses pembelajaran sehingga dapat merencanakan, memantau, dan mengevaluasi apa yang dipelajari (Bahri \& Corebima, 2015; Huang \& Newbern, 2012). Adapun indikator untuk mengukur metakognitif dalam diri 
siswa (Schraw \& Moshman, 1995), yaitu: pengetahuan deklaratif (declarative knowledge), pengetahuan prosedural (procedural knowledge), pengetahuan kondisional (conditional knowledge), perencanaan (planning), strategi manajemen informasi (information management strategies), monitoring (monitoring), strategi perbaikan (debugging strategies), dan evaluasi (evaluation).

Selain metakognitif, faktor internal yang mempengaruhi hasil belajar adalah keyakinan seseorang bahwa ia dapat melakukan tugas tertentu dan menghadapi tantangan yang ada untuk mencapai tujuan tertentu dengan yakin dan percaya diri akan kemampuan yang dimilikinya untuk dapat berhasil dalam kegiatan belajarnya dalam mencapai tujuan pembelajaran. Keyakinan seperti ini disebut sebagai efikasi diri (self-efficacy). Secara etimologi terdiri dari dua kata yaitu "self" yang berarti unsur struktur kepribadian dan "efficacy" yang berarti penilaian diri, apakah seseorang dapat melakukan tindakan yang baik atau buruk, benar atau salah, bias atau tidak mengerjakan sesuatu yang sesuai dengan yang dipersyaratkan (Alwisol, 2010). Efikasi diri (self-efficacy) sebagai penilaian seseorang tentang kemampuanya sendiri untuk menjalankan perilaku tertentu atau mencapai tujuan tertentu (Omrod, 2009). Menurut teori kognitif sosial Bandura, perasaan seseorang atas efikasi diri (self-efficacy) yang dimilikinya mempengaruhi beberapa aspek perilaku mereka, termasuk pilihan kegiatan mereka, usaha dan ketekunan mereka, dan terakhir belajar dan prestasi mereka (Bandura, 1986, 1989, 1977; Schunk, 1989, 1991 dalam (Chularut \& Debacker, 2004). Pengukuran efikasi diri (self efficacy) yang dimiliki seseorang mengacu pada tiga dimensi yaitu: Magnitude atau Level, Strength, dan Generality (Bandura, 2006).

Premis dasar dari teori efikasi diri (self-efficacy) adalah kepercayaan seseorang dalam kemampuannya untuk mencapai hasil yang diinginkan dari tindakan yang dilakukan, hal tersebut merupakan penentu perilaku bagi seseorang ketika memilih apakah seseorang tersebut akan terlibat dan gigih dalam menghadapi rintangan dan tantangan atau sebaliknya (Maddux, 2000). Efikasi diri (self-efficacy) sebagai penilaian diri, apakah seorang individu dapat melakukan tindakan yang baik atau buruk, tepat atau salah, dan bisa atau tidak bisa mengerjakan tugas sesuai dengan yang dipersyaratkan. Efikasi diri menggambarkan penilaian akan kemampuan diri. Individu yang memiliki efikasi yang tinggi akan memiliki kepercayaan bahwa dirinya mampu mengerjakan suatu tugas sesuai tuntutan situasi, bekerja keras, dan bertahan untuk mengerjakan tugas tersebut sampai selesai (Alwisol, 2010). Dengan demikian metakognitif dan efikasi diri (self-efficacy) penting dimiliki siswa dalam belajarnya terutama pada pelajaran ilmu ekonomi yang merupakan studi mengenai bagaimana orang-orang dan masyarakat membuat pilihan, dengan cara atau tanpa penggunaan uang, dengan menggunakan sumber daya yang terbatas tetapi dapat digunakan dalam berbagai cara untuk menghasilkan berbagai jenis barang dan jasa dan mendistribusikannya untuk keperluan konsumsi sekarang dan di masa mendatang, kepada berbagai orang dan golongan masyarakat. Ilmu ekonomi menganalisis biaya dan keuntungan serta memperbaiki corak penggunaan sumber-sumber daya (Samuelson, 2004).

Pendekatan yang digunakan dalam penelitian ini untuk mengatasi masalah dari hasil belajar menggunakan teori belajar sosial kognitif Bandura 
(1976) yang menyatakan bahwa efikasi diri (self-efficacy) dipengaruhi oleh interaksi antara tingkah laku, faktor diri (misalnya pemikiran termasuk metakognitif, motivasi) dan kondisi lingkungan seseorang (Bandura, 1976), (Bandura, 1986, 1997 dalam (Pintrich. R. Paul, 2003). Menurut teori kognitif sosial Bandura, dimana perasaan seseoorang atas efikasi diri (self-efficacy) yang dimilikinya mempengaruhi beberapa aspek perilaku mereka, termasuk pilihan kegiatan mereka, usaha dan ketekunan mereka, dan terakhir belajar dan prestasi mereka (Bandura, 1986, 1989, 1977; Schunk, 1989, 1991 dalam (Chularut \& Debacker, 2004). Efikasi diri (self-efficacy) mempunyai peranan yang penting dalam pembentukan metakognitif (Bandura, 1997; Kurbanoglu, 2003). Dan faktor-faktor yang mempengaruhi hasil belajar dikelompokkan menjadi dua yaitu: pertama, faktor internal yang meliputi faktor fisiologi (kondisi fisiologi dan kondisi panca indra), dan faktor psikologi (minat, efikasi diri (self efficacy), motivasi, kemandirian belajar, bakat, dan kemampuan kognitif termasuk kemampuan metakognitif); kemudian yang kedua, faktor eksternal meliputi faktor lingkungan (alam, sosial, budaya), dan faktor instrumental (Djamarah \& Bahri, 2011).

\section{METODE PENELITIAN}

Metode penelitian yang digunakan adalah survey menggunakan pendekatan deskriptif. Penelitian deskriptif adalah penelitian yang menggambarkan sifat suatu keadaan yang sementara berjalan pada saat penelitian dilakukan dan memeriksa sebab-sebab dari suatu gejala tertentu (Travers, 1978), (Sevilla, Ochave, Punsalan, Regala, \& Uriarte, 1993). Populasi dalam penelitian ini adalah jumlah seluruh siswa kelas XI IPS SMA Negeri Se-Kota Bandung tahun pelajaran 2017/2018. Untuk memperoleh jumlah yang representatif, (Marzano, 2003) memberikan petunjuk bahwa apabila subjek kurang dari 100 lebih baik diambil seluruhnya sehingga penelitian merupakan penelitian populasi. Selanjutnya jika subjeknya besar, dapat diambil antara 10\%-15\% atau 20\%- 25\% atau lebih tergantung setidaktidaknya dari:

1. Kemampuan peneliti dilihat dari waktu, tenaga, dan dana.

2. Sempit luasnya wilayah pengamatan dari setiap subjek, karena hal ini menyangkut dari banyak sedikitnya data.

3. Besar kecilnya resiko yang ditanggung oleh peneliti.

Berdasarkan pendapat tersebut, maka sampel yang diambil dalam penelitian ini adalah $25 \%$ dari 27 sekolah yaitu 6 sekolah dan sampel siswa diambil dengan menggunakan teknik proporsional random sampling. Untuk mengukur tingkat metakognitif dan tingkat efikasi diri (self efficacy) pengumpulan data dilakukan dalam bentuk angket sedangkan data hasil belajar siswa diperoleh dari nillai Ujian Akhir Semester (UAS) mata pelajaran Ekonomi tahun pelajaran 2017/2018. Adapun ukuran yang digunakan dalam bentuk skala Likert. Alternatif jawaban pada skala Likert terdiri dari Selalu (SL), Sering (SR), Kadang-Kadang (KD), Jarang (JR), Tidak Pernah (TP). Pemberian skor pada skala ini adalah 1 sampai 5. 
Data diolah menggunakan bantuan program SPSS 22. Data dianalisis menggunakan analisis jalur (Path Analysis) mengenai pengaruh langsung (Direct Effect) dan pengaruh tidak langsung (Indirect effect) dari variabelvariabel dari penelitian ini. Besarnya standar error tidak langsung (S $\rho Y X 1 \rho Y X 2)$ dihitung dengan rumus Sobel Test sebagai berikut:

\section{$\left.S \rho Y X_{1} \rho Y X_{2}\right)=\sqrt{\left.\left.\left.\left(\rho Y X_{2}\right)^{2} S p X_{2} X_{1}\right)^{2}+\left(p X_{2} X_{1}\right)^{2} S\left(p Y X_{2}\right)^{2}+S \rho X_{2} X_{1}\right)^{2} S\left(\rho X_{2}\right)^{2}\right)}$}

Rumus Sobel Test dapat dipakai pada jumlah sampel yang besar dan nilai koefisien mediasi berdistribusi normal. Menurut (Bollen dan Stine, 1990) pada sampel kecil distribusinya umumnya tidak normal (Ghozali, 2013; Preacher and Hayes, 2004).

\section{HASIL PENELITIAN DAN PEMBAHASAN}

Secara ringkas, skor rata-rata setiap variabel yaitu metakognitif $\left(\mathrm{X}_{1}\right)$, efikasi diri (self efficacy) $\left(\mathrm{X}_{2}\right)$, dan hasil belajar (Y) siswa kelas XI IPS SMA Negeri Se-Kota Bandung dapat dilihat pada tabel 1 berikut ini:

Tabel 1. Ringkasan Skor Rata-Rata Antar Variabel

\begin{tabular}{lccc}
\hline \multicolumn{1}{c}{ Variabel } & Skor Rata-Rata & Keterangan & $\begin{array}{c}\text { Penafsiran per } \\
\text { Variabel }\end{array}$ \\
\hline Metakognitif $\left(\mathrm{X}_{1}\right)$ & 3,20 & Tinggi & Tinggi \\
Efikasi Diri (Self Efficacy) $\left(\mathrm{X}_{2}\right)$ & 3,40 & Tinggi & Tinggi \\
Hasil Belajar (Y) & Rentang nilai & Sedang & Sedang \\
& $80-87$ & & \\
\hline
\end{tabular}

Hasil analisis deskriptif menunjukkan skor rata-rata untuk variabel metakognitif adalah 3,20. Hal ini menunjukkan tingkat metakognitif siswa kelas XI IPS SMA negeri Se-Kota Bandung berada pada kategori tinggi. Skor rata-rata untuk variabel efikasi diri (self efficacy) adalah 3,40. Hal ini menunjukkan tingkat efikasi diri (self efficacy) siswa kelas XI IPS SMA Negeri Se-Kota Bandung berada pada kategori sangat tinggi. Skor hasil belajar siswa sebagian besar berada pada kategori sedang dengan rentang skor 79-87 yaitu sebanyak 63,81\% atau 231 responden. Hal ini menunjukkan hasil belajar siswa kelas XI IPS untuk mata pelajaran Ekonomi di SMA negeri Se-Kota Bandung cukup tinggi.

Berdasarkan koefisien jalur yang tertera pada Gambar 1, maka dapat dibuat persamaan struktur sebagai berikut:

1. Persamaan Struktur 1: $\mathrm{X}_{2}=\rho \mathrm{X}_{2} \mathrm{X}_{1}+\mathrm{e}_{1}$

$$
=0,728 \mathrm{X}_{1}+\mathrm{e}_{1}
$$

2. Persamaan Struktur 1: $\mathrm{Y}=\rho \mathrm{YX}_{1}+\rho \mathrm{YX}_{2}+\mathrm{e}_{2}$

$$
=0,578 \mathrm{X}_{1}+0,357 \mathrm{X}_{2}+\mathrm{e}_{2}
$$

Pengujian hipotesis dalam penelitian ini menggunakan analisis jalur (Path Analysis). Hasil dari analisis jalur dengan bantuan SPSS 22 dapat dilihat pada Gambar 1 berikut ini: 


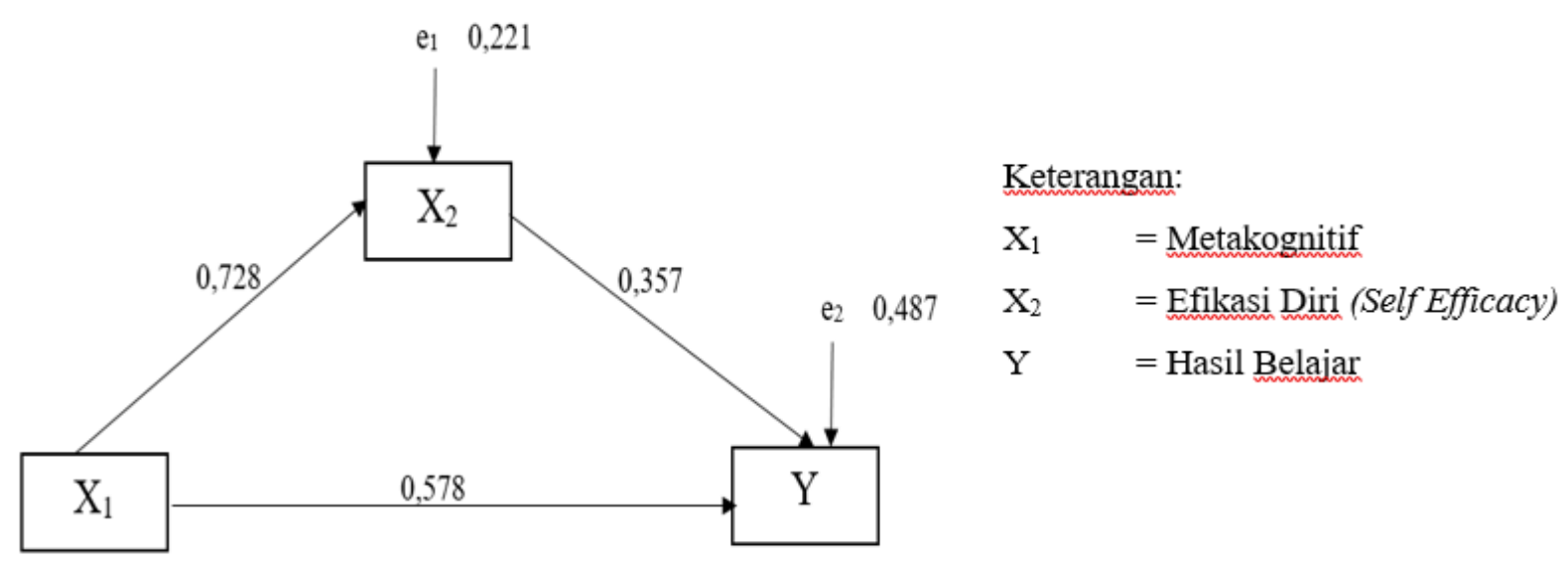

Gambar 1. Diagram Hasil Analisis Jalur

Untuk melihat seberapa besar pengaruh langsung, pengaruh tidak langsung dan pengaruh total dapat dilihat pada tabel 2 yang merupakan tabel dekomposisi koefisien jalur sebagai berikut:

Tabel 2. Dekomposisi Pengaruh Antar Variabel

Pengaruh

\begin{tabular}{ccc}
\multicolumn{3}{c}{ Pengaruh } \\
\hline Langsung & Tidak Langsung & Total $(\mathrm{TE})$ \\
$(\mathrm{DE})$ & $(\mathrm{DE})$ & \\
0,728 & - & 0,728 \\
0,578 & 0,357 & 0.935 \\
\hline
\end{tabular}

Berdasarkan Tabel 2 menunjukkan koefisien yang berpengaruh langsung dari $\mathrm{X}_{1}$ ke $\mathrm{X}_{2}$ sebesar 0,728 (pengaruh total). Dan untuk $\mathrm{X}_{1}$ ke $\mathrm{Y}$ berpengaruh langsung sebesar 0,578 dan berpengaruh tidak langsung (melalui $\mathrm{X}_{2}$ ) sebesar 0,357 menjadi $0,578+0,357=0,935$. sehingga diperoleh pengaruh total $\mathrm{X}_{1} \mathrm{ke}$ Y sebesar 0,935.

Tabel 3. Hasil Uji Goodness of Fit Model

\begin{tabular}{cccccc}
\hline \multicolumn{1}{c}{ Pengaruh Variabel } & Fhitung & $\mathrm{F}_{\text {tabel }}$ & thitung & tabel & Sig \\
\hline $\mathrm{X}_{1}$ terhadap X & 40,551 & 3,8674 & 11,941 & 1,9665 & 0,000 \\
$\mathrm{X}_{1}$ terhadap Y melalui X & 576,440 & 3,8674 & 91,838 & 1,9665 & 0,000 \\
\hline
\end{tabular}

Berdasarkan Tabel 3 menunjukkan pengaruh $\mathrm{X}_{1}$ terhadap $\mathrm{X}_{2}$ dengan nilai Fhitung sebesar 40,551 $>F_{\text {tabel }}$ sebesar 3,8674 pada $\mathrm{df}=361(\mathrm{df}=\mathrm{N}-1=362-1)$ dengan tingkat signifikansi atau propabilitas 0,000 yang berarti model regresi penelitian ini dapat dipakai untuk memprediksi tingkat metakognitif terhadap efikasi diri (self efficacy). Hasil uji signifikansi dengan uji t diperoleh nilai thitung sebesar $11,941>$ tabel sebesar 1,9665 dengan $\mathrm{df}=361$ dan nilai signifikansi 0,000. Dengan demikian, dapat disimpulkan bahwa terdapat pengaruh signifikan antara tingkat metakognitif terhadap efikasi diri (self 
efficacy). Pengaruh $\mathrm{X}_{1}$ terhadap $\mathrm{Y}$ melalui $\mathrm{X}_{2}$ dengan nilai $\mathrm{F}_{\text {hitung }}$ sebesar $576,440>F_{\text {tabel }}$ sebesar 3,8674 pada $\mathrm{df}=361(\mathrm{df}=\mathrm{N}-1=362-1)$ dengan tingkat signifikansi atau propabilitas 0,000 yang berarti model regresi penelitian ini dapat dipakai untuk memprediksi tingkat metakognitif terhadap hasil belajar baik secara langsung maupun tsecara tidak langsung (melalui efikasi diri (self efficacy). Hasil uji signifikansi dengan uji t diperoleh nilai thitung sebesar 91,838 $>$ tabel sebesar 1,9665 dengan $\mathrm{df}=361$ dan nilai signifikansi 0,000. Dengan demikian, dapat disimpulkan bhwa terdapat pengaruh signifikan antara tingkat metakognitif terhadap hasil belajar baik secara langsung maupun tsecara tidak langsung (melalui efikasi diri (self efficacy).

\section{Metakognitif berpengaruh positif dan signifikan terhadap efikasi diri (self efficacy)}

Hasil analisis pada persamaan struktur 1 dengan analisis regresi menggunakan program SPSS 22 menunjukkan hasil output dengan nilai standardized beta metakognitif sebesar 0,728 dan nilai signifikansi adalah 0,000 yang berarti terdapat pengaruh yang positif dan signifikan antara metakognitif terhadap efikasi diri (self efficacy). Besarnya pengaruh metakognitif terhadap efikasi diri (self efficacy) adalah sebesar $(0,728)^{2}$ atau sebesar 53,0\%, sedangkan sisanya sebesar $47,0 \%$ dipengaruhi oleh variabel lain yang tidak dijelaskan dalam model penelitian ini. Hal ini menunjukkan bahwa semakin tinggi tingkat metakognitif maka akan diikuti dengan semakin tingginya tingkat efikasi diri (self efficacy) siswa. Hal ini sejalan dengan teori Albert Bandura menjelaskan bahwa efikasi diri (self-efficacy) dipengaruhi metakognitif dan motivasi (Bandura, 1986, 1997 dalam (Pintrich. R. Paul, 2003). Beberapa penelitian juga menyatakan bahwa efikasi diri (self-efficacy) diindikasikan mempunyai peranan yang penting dalam pembentukan metakognitif adalah (Magno, 2009), (Coutinho \& Neuman, 2008; GutiérrezBraojos, 2013; Johnson, Gueutal, \& Falbe, 2009; Kahraman \& Sungur, 2012; Kiran \& Sungur, 2012; Magno, 2009; Peng et al., 2014; Sen, 2016; Şenol Şen, 2016; Stewart, Seifert, \& Rolheiser, 2015; Yerdelen-Damar \& Peşman, 2013).

Hasil penelitian ini sejalan dengan penelitian (Ibrahim et al., 2010) bahwa efikasi diri (self efficacy), nilai-tugas, pengaturan diri, dan elaborasi siswa secara signifikan berpengaruh positif dengan metakognitif. Dan efikasi diri (self efficacy) sebagai prediktor terkuat dari skor total secara keseluruhan variabel yang diteliti. Hasil penelitian ini sejalan dengan penelitian (Moores, Chang, Smith, 2006) bahwa efikasi diri (self efficacy) dan metakognisi adalah konstruksi yang berbeda tetapi saling berkaitan.

Dengan demikian, dapat disimpulkan bahwa siswa yang memiliki metakognitif yang baik mampu mengontrol proses belajarnya sendiri dari mulai membuat rencana pembelajaran, memilih strategi belajar yang sesuai dengan kemampuannya sendiri, memantau perkembangan belajarnya sambil mengoreksi pemahamannya, sampai tujuan pembelajaran yang diharapkan dapat tercapai akan berpengaruh terhadap efikasi diri (self efficacy) siswa dengan merasa yakin dan percaya diri akan kemampuan yang dimilikinya dalam mengerjakan tugas pelajaran, mengerjakan soal ujian dan mengahadapi 
tantangan belajar, sehingga pada akhirnya siswa mampu memahami informasi pembelajaran dan materi pelajaran yang disampaikan oleh guru.

Metakognitif berpengaruh positif dan signifikan terhadap hasil belajar ekonomi siswa baik secara langsung maupun tidak langsung (melalui efikasi diri (self efficacy)

Hasil analisis pada persamaan struktur 2 dengan analisis regresi menggunakan program SPSS 22 menunjukkan nilai standardized beta untuk metakognitif sebesar 0,578 dan efikasi diri (self efficacy) sebesar 0,357. Untuk besarnya nilai e 1 adalah $\sqrt{(\mathbf{1 - 0 , 5 3 0 )}}=0,221$ dan besarnya nilai e 2 adalah $\sqrt{(\mathbf{1 - 0 , 7 6 3 )}}=0,487$. Hasil analisis jalur menunjukkan bahwa metakognitif dapat berpengaruh langsung terhadap hasil belajar sebesar 0,578 dan pengaruh tidak langsungnya yaitu dari metakognitif melalui efikasi diri (self efficacy) lalu ke hasil belajar yaitu $(0,578) \times(0,357)=0,206$. Maka total pengaruh metakognitif terhadap hasil belajar secara langsung maupun tidak langsung adalah $(0,578+0,357)=0,935$ atau sebesar $87,4 \%$.

Pengujian signifikansi pengaruh variabel intervening akan diuji dengan menggunakan Sobel Test dengan menghitung standar error dari koefisien indirect effect $\left(\mathrm{S} \rho \mathrm{YX}_{1} \rho \mathrm{YX}_{2}\right)$ sebagai berikut:

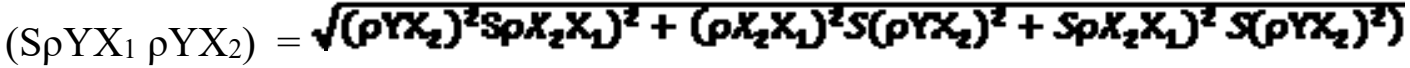 $\left(\mathrm{S}_{\rho} \mathrm{YX}_{1} \rho \mathrm{YX}_{2}\right)=\sqrt{(\mathbf{0 , 3 5 7})^{2} \times(\mathbf{0 , 0 0 8})^{2}+(\mathbf{0 , 7 2 8})^{2} \times(\mathbf{0 , 0 0 7})^{2}+(\mathbf{0 , 0 0 3})^{2} \times(\mathbf{0 , 0 0 7})^{2}}$ $\left({\left.\mathrm{S} \rho Y X_{1} \rho \mathrm{YX}_{2}\right)}=0,0107\right.$}

Berdasarkan hasil $\left(\mathrm{Sp}^{2} \mathrm{p}^{3}\right)$ tersebut, maka nilai 0,0203 $<0,05$ sehingga dapat disimpulkan bahwa koefisien mediasi berpengaruh signifikan. Dengan demikian dapat disimpulkan bahwa metakognitif berpengaruh secara positif dan signifikan terhadap hasil belajar ekonomi baik secara langsung maupun secara tidak langsung (melalui efikasi diri (self efficacy). Hal ini menunjukkan bahwa siswa yang memiliki kemampuan metakognitif yang tinggi akan mempengaruhi efikasi diri (self efficacy) siswa dalam menghadapi tugas-tugas ataupun tantangan belajar dengan yakin dan percaya diri akan kemampuannya sendiri sehingga akan lebih rajin belajar untuk mencapai tujuan yang telah ditetapkan salah satunya adalah meningkatkan hasil belajarnya. Hasil penelitian ini sejalan dengan (Jane I. Gravill, Deborah R. Compeau and Barbara L. Marcolin. (2002) menunjukkan efikasi diri (self-efficacy) dan kesadaran diri mempengaruhi proses metakognitif individu dan berkontribusi terhadap hasil belajar dalam pembelajaran mandiri.

Hasil penelitian ini sejalan dengan penelitian (Tuhardjo, Juliardi, Rafsanjani, 2016) bahwa terdapat pengaruh positif yang signifikan antara efektivitas belajar terhadap hasil belajar pada pelajaran Akuntansi Keuangan. Terdapat juga pengaruh positif signifikan dari efikasi diri (self efficacy) terhadap hasil belajar Akuntansi Keuangan Intermediate 1. Hasil penelitian ini sejalan dengan penelitian (Köseoğlu, 2015) bahwa efikasi diri (self efficacy) berpengaruh terhadap prestasi akademiknya dimana siswa yang percaya dan yakin dengan kemampuan yang dimilikinya dapat meningkat dengan berusaha 
dan memiliki efikasi diri (self efficacy) yang tinggi sehingga dapat meningkatkan prestasi akademiknya. Hasil penelitian ini juga sejalan dengan pendapat (Margolis, H., \& McCabe, 2006) menjelaskan bahwa efikasi diri (self efficacy) sebagai penilaian diri tentang kemampuan mereka untuk sukses dalam sebuah tugas spesifik atau serangkaian tugas yang berhubungan dengan kegiatan belajarnya. Efikasi diri (self efficacy) menunjukkan kepada keyakinan akan kemampuan dirinya untuk menggerakan motivasi, sumber-sumber kognitif termasuk metakognitif dan serangkaian tindakan yang diperlukan untuk menghadapi situasi (Wood, R.E.,\& Locke, 1987). Efikasi diri (self efficacy) membantu untuk menentukan berapa banyak usaha, ketekunan dan ketahanan saat menyelesaikan tugas. Dengan kata lain, semakin tinggi rasa keberhasilan, semakin besar usaha, ketekunan dan ketahanan (Mahyudin. R, 2006).

\section{SIMPULAN}

Berdasarkan uraian hasil penelitian, tingkat metakognitif siswa termasuk kedalam kategori tinggi, tingkat efikasi diri (self efficacy) termasuk kedalam kategori tinggi, dan hasil belajar ekonomi siswa termasuk kedalam kategori sedang. Hasil dari uji hipotesis menunjukan bahwa metakognitif berpengaruh positif dan signifikan terhadap efikasi diri (self efficacy); metakognitif yang berpengaruh positif dan signifikan terhadap hasil belajar ekonomi baik secara langsung maupun tidak langsung (melalui efikasi diri (self efficacy). Berdasarkan hasil penelitian yang telah dilakukan, maka saran penulis adalah guru sebaiknya memperhatikan tingkat metakognitif dan efikasi diri (self efficacy) siswa yang disesuaikan dengan metode pembelajaran yang diterapkan guru dalam proses pembelajaran. Bagi siswa yang memiliki hasil belajar yang rendah, sebaiknya lebih memperhatikan persiapan atau rencana pembelajaran dan strategi belajar yang sesuai dengan kemampuannya, serta memperbaiki, meninjau dan mengevaluasi kembali kegiatan belajarnya secara teratur. Bagi peneliti selanjutnya hendaknya dapat meneliti dan memperdalam kembali permasalahan yang berkaitan dengan faktor-faktor yang mempengaruhi hasil belajar selain dari metakognitif dan efikasi diri (self efficacy) siswa.

\section{DAFTAR RUJUKAN}

Adam, S. 2004. Using Learning Outcome: A Consideration of The Nature, Role, Application and Implication for The European Educationn of Employing Learning Outcome at The Local, National and International Levels.

Alwisol. 2010. Psikologi Pendidikan. Malang: UMM Press.

Bahri, A., \& Corebima, A. D. 2015. The contribution of learning motivation and metacognitive skill on cognitive learning outcome of students within different learning strategies. Journal of Baltic Science Education, 14(4), $487-500$. 
Bandura, A. 1976. Sosial Learning Theory. Englewood Cliffs, New Jersey: A Paramount Communications Company.

Bandura, A. 1986. Social Foundation Of Thought and Action: A Social Cognitive theory. New Jersey: Prentice-Hall.

Bandura, A. 1997. Self-Efficacy (The Exercise of Control). New York: W. H. Freeman and Company.

Bandura, A. 2006. Guide for Constructing Self-Efficacy Scales. Self-Efficacy beliefs of Adolescents. Chapter 14.

Bollen, K. A., \& Stine, R. 1990. Direct and indirect effects: Classical and bootstrap estimates of variability. Sociological Methodology, 20, 115140

Cañada, M. D., \& Arumí, M. 2015. Educational Research and Evaluation : An International Journal on Theory and Practice Self-regulating activity : use of metacognitive guides in the interpreting classroom. Educational Research and Evaluation: An International Journal on Theory and Practice, 245-264. https://doi.org/10.1080/13803611.2012.661934

Chularut, P., \& Debacker, T. K. 2004. The Influence of Concept Mapping on Achievement, Self-Regulation, and Self-Efficacy in Students of English as A Second Language. Contemporary Educational Psychology, 29, 248263. https://doi.org/10.1016/j.cedpsych.2003.09.001

Coutinho, S. A., \& Neuman, G. 2008. A model of metacognition, achievement goal orientation, learning style and self-efficacy. Learning Environments Research, 11(2), 131-151. https://doi.org/10.1007/s10984-008-9042-7

Djamarah, \& Bahri, S. 2011. Psikologi Belajar. Banjarmasin: Penerbit Rineka Cipta.

Flavell, J. 1979. Metacognition and cognitive monitoring: A new area of cognitive-developmental inquiry. In American Psychologist (Vol. 34, pp. 906-911).

Flavell, J. H., Shipstead, S. G., \& Croft, K. 1980. What young children think you see when their eyes are closed. In Cognition (Vol. 8, pp. 369-387).

Garrett, A. J., Mazzocco, M. M. M., \& Baker, L. 2006. Development of the Metacognitive Skills of Prediction and Evaluation in Children With or Without Math Disability. Learning Disabilities Research \& Practice : A Publication of the Division for Learning Disabilities, Council for Exceptional Children, 21(2), 77-88. https://doi.org/10.1111/j.15405826.2006.00208.x 
Ghozali, I. 2013. Aplikasi Analisis Multivariate Dengan Program IBM SPSS 21 Update PLS Regresi. Badan Penerbit Universitas Diponegoro. Semarang.

Goh, C. 2016. Metacognitive Instruction for Second Language Listening Development: Theory, Practice and Research Implications. Regional Language Centre Journal, 39(2), 188-213. https://doi.org/10.1177/0033688208092184

Gutiérrez-Braojos, C. 2013. Future time orientation and learning conceptions: effects on metacognitive strategies, self-efficacy beliefs, study effort and academic achievement. Educational Psychology, 3410(March 2014), 121. https://doi.org/10.1080/01443410.2013.858101

Huang, Jiuhuan \& Newbern, Claudia. 2012. The Effects of Metacognitive Reading Strategy Instruction on Reading Performance of Adult ESL Learners with Limited English and Literacy Skills. Journal of Research and Practice for Adult Literacy, Secondary, and Basic Educatio, 1(2), 66-78.

Ibrahim S. Al-Harthy, I. S., and Christopher A. 2010. Goals, Efficacy and Metacognitive Self-Regulation A Path Analysis. International Journal of Education, 2(1), pp 1-20.

Jane I. Gravill, Deborah R. Compeau and Barbara L. Marcolin. 2002. Metacognition and it: The Influence of Self-Efficacy and SelfAwareness. Eighth Americas Conference on Information Systems. 10551064.

Johnson, R. D., Gueutal, H., \& Falbe, C. M. 2009. Technology, trainees, metacognitive activity and e-learning effectiveness. Journal of Managerial Psychology, 24(6), 545-566. https://doi.org/10.1108/02683940910974125

Kahraman, N., \& Sungur, S. 2012. Antecedents and Consequences of Middle School Students' Achievement Goals in Science. Asia-Pacific Education Researcher (De La Salle University Manila), 21(3), 535-551. https://doi.org/10.1007/s40299-012-0024-2.

Kesici, S., Erdogan, A., \& Özteke, Irem, H. 2011. Are The Dimensions of Metacognitive Awareness Differing in Prediction of Mathematics and Geometry Achievement? Procedia Social and Behavioral Sciences Social, 15, 2658-2662. https://doi.org/10.1016/j.sbspro.2011.04.165

Kiran, D., \& Sungur, S. 2012. Sources and Consequences of Turkish Middle School Students' Science Self-Efficacy. Asia-Pacific Education Researcher, 21(1), 172-180. Retrieved from <Go to ISI>://000302255900017 
Köseoğlu, Y. 2015. Self-Efficacy and Academic Achievement-A Case From Turkey. Journal of Education and Practice, 6(29).

Kurbanoglu, S, S. 2003. Self-efficacy: A Concept Closely Linked to Information Literacy and Lifelong Learning. Journal of Documentation, 59(6), 635-646. https://doi.org/10.1108/00220410310506295

Listiana, L., Susilo, H., Suwono, H., \& Suarsini, E. 2016. Empowering Students' Metacognitive Skills Through New Teaching Strategy (Group Investigation Integrated With Think Talk Write in Biology Classroom. Journal of Baltic Science Education, 15(3), 391-400.

Maddux. 2000. Self-Efficacy: He Power of Believing You Can. In S. C, R \& J. Lopez, Shane (Eds.), Handbook of Positive Psychology (p. 709). New York: Oxford University Press.

Magno, C. 2009. Investigating the Effect of School Ability on Self-efficacy, Learning Approaches, and Metacognition. The Asia-Pacific Education Researcher, 18(2), 233-244. https://doi.org/10.3860/taper.v18i2.1325

Mahyudin. R. 2006. The Relationship Between Student's Self Efficacy and Their English Language Achievemeny. Jurnal Pendidik Dan Pendidikan. Jilid 21, 61-71.

Margolis, H., \& McCabe, P. P. 2006. Improving (Self Afficacy) and Motivation What To Do, WhatTto Say. Intervention in School and Clinic, 41(4).

Marzano, R. J. 2003. What Works in Schools: Translating Research Into Action. ASCD.

Moores, T. T., Chang, J. C., Smith, D. K. 2006. Clarifying the Role of SelfEfficacy and Metacognition as Indicators of Learning: Construct Development and Test. The DATA BASE for Advances in Information Systems, 37(2 \& 3), 125-132.

Ninik Kristiani, Herawati Susilo, F. R. \& D. C. A. 2015. The contribution of students' metacognitive skills and scientific attitude towards their academic achievements in biology learning implementing Thinking Empowerment by Questioning (TEQ) learning integrated with inquiry learning (TEQI). International Journal of Educational Policy Research and Review, 2(9), 113-120.

Omrod, J. E. 2009. Psikologi Pendidikan Jilid 1. Jakarta: Erlangga.

Peng, Y., Hong, E., \& Mason, E. 2014. Motivational and cognitive test-taking strategies and their influence on test performance in mathematics. 
Educational Research and Evaluation, 20(5), 366-385. https://doi.org/10.1080/13803611.2014.966115

Pintrich. R. Paul, S. M. G. 2003. Intentional Conceptual Change. Lawrence Erlbaum Associates, Inc., Publishers.

PISA. 2015. Assessment and Analytical Framework Science, Reading, Mathematic, Financial Literacy and Collaborative Problem Solving. PISA: OECD Publishing: http://www.oecd.org/publications/pisa-2015assessment-and-analytical-framework-9789264281820-en.htm.

Preacher, K. J and Hayes, A. F., 2004. SPSS and SAS Procedures for Estimating Indirect Effects in Simple Mediation Models. Behavior Research Methods, Instruments, \& Computers, 36 (4), 717-731. Psychonomic Society, Inc.

Raes, A., Schellens, T., De Wever, B., \& Benoit, D. F. 2016. Promoting metacognitive regulation through collaborative problem solving on the web: When scripting does not work. Computers in Human Behavior, 58, 325-342. https://doi.org/10.1016/j.chb.2015.12.064

Samuelson, Paul, A., dan Nordhaus, William, D. 2004. Ilmu Makro Ekonomi. Jakarta : PT. Media Edukasi.

Schraw, G., \& Moshman, D. 1995. Metacognitive Theories. In Educational Psychology Review (pp. 351-371). New York: JSTOR.

Schunk, H, D. 1985. Self-efficacy and Classroom Learning. Psychology in The School, 22, 208-223.

Scott, I. 2011. The Learning Outcome In Higher Education: Time to Think Again. Worcester Journal of Learning and Teaching.

Şenol, Ş. 2016. Modeling The Structural Relations Among Learning Strategies, Self-Efficacy Beliefs, and Effort Regulation. Problems Of Education in The 21st Century, 71, 62.

Şenol, Ş. 2016. The relationship between secondary school students' selfregulated learning skills and Chemistry Achievement. Journal of Baltic Science Education, 15(3), 312-324.

Sevilla, C. G., Ochave, J. A., Punsalan, T. G., Regala, B. P., \& Uriarte, G. G. 1993. Pengantar Metode Penelitian. Jakarta: Universitas Indonesia Press.

Shen, C., \& Liu, H. 2011. Metacognitive Skills Development: A Web-Based Approach in Higher Education. The Turkish Online Journal of Educational Technology, 10(2), 140-151.

Slameto. 2010. Belajar dan Faktor-faktor yang Mempengaruhi. Jakarta: Rineka Cipta. 
Stewart, G., Seifert, T. A., \& Rolheiser, C. 2015. Anxiety and self-efficacy's relationship with undergraduate students' perceptions of the use of metacognitive writing strategies. The Canadian Journal for the Scholarship of Teaching and Learning, 6(1), 19. https://doi.org/http://dx.doi.org/10.5206/cjsotl-rcacea.2015.1.4

Sudjana, N. 2012. Penilaian Hasil Proses Belajar Mengajar. Bandung: PT Remaja Rosadakarya.

Susanto, A. 2013. Teori Belajar dan Pembelajaran di Sekolah Dasar. Jakarta: Kencana Prenada Media Group.

Tok, Ş. 2013. Effects of The Know-Want-Learn Strategy on Students ' Mathematics Achievement, Anxiety and Metacognitive Skills. Metacognition Learning, 8, 193-212. https://doi.org/10.1007/s11409013-9101-z

Travers, M. W. R. 1978. An Inttoduction to Educational Research. New York: Mac Milan Publishing Co., Inc.

Tuhardjo, Juliardi, D., \& Rafsanjani, A. M. 2016. The Effect of Learning Effectiveness and Self-Efficacy on Intermediate Financial Accounting I Learning outcome . Journal Of Humanities And Social Science (IOSRJHSS), 21(9), pp 01-09. doi: 10.9790/0837-2109080109

Widarwati, S. 2007. Implementasi Model Pembelajaran Team Games Tournament Berbasis Teknologi Informasi pada Perkulihan Kajian Mode. Majalah Ilmiah Pendidikan, 3, 224-239.

Wood, R.E.,\& Locke, E. A. 1987. The Relation of (Self Efficacy) and Gradegoals to Academic Performance. Educational and Psychological Measurement, 47(4).

Yerdelen-Damar, S., \& Peşman, H. 2013. Relations of Gender and Socioeconomic Status to Physics Through Metacognition and SelfEfficacy. Journal of Educational Research, 106, 280-289. https://doi.org/10.1080/00220671.2012.692729 
